\title{
Analysis of Management Functions on Registration of Porda XIII Participants in Bogor District
}

\author{
Sitti Sofiah \\ Physical Education, Universitas Negeri Jakarta, Jl. R.Mangun Muka Raya No.11, East Jakarta \\ City, DKI Jakarta 13220, Indonesia \\ Email: sittisofiah27@gmail.com
}

\begin{abstract}
This research is motivated by the problems in the implementation of Porda Jabar XIII in 2018 held in Bogor Regency. Porta Jabar XIII is a multievent sports competition involving 9,650 athletes and 3,800 officials. Its implementation is greatly influenced by the application of management functions, especially in the registration of participants. The purpose of this study was to analyze management functions in the registration of Porda Jabar XIII participants. The theory that underlies this research relates to sports theory in general, the theory of the implementation of sports competitions, and management theory. The study results indicate that the management function consisting of planning, organizing, actuating, and controlling (POAC) has been applied to the registration of participants.
\end{abstract}

Keyword: multievent sports, management function

(C) 2021 Sitti Sofiah

Under the license CC BY-SA 4.0

\section{INTRODUCTION}

Sports are a series of activities that involve body movement and are carried out to increase endurance (Rubiyatno, 2014). Sport is almost impossible to separate from human life. It can be said; sport is one of the basic needs in life (Bangun, 2019). It is impossible to have someone in life who does not exercise at all and does not need it. Everyone needs exercise, no matter who he is and how old he is (Prasetyo, 2015). Sports can be done since childhood, even for the elderly with different needs. At the age of children, exercise helps their body grow and develop as they get older. Meanwhile, the activity carried out by the elderly (elderly) is to keep the body feeling fit, muscles and bones stay strong.

However, along with the development of science, sport is no longer only known as physical activity. More than that, sport is then considered a discipline also studied in Indonesia's education process (Rohendi \& Rustiawan, 2020). Of course, 
something must have some unique aspects called a science, such as the objective, systematic, methodical, and universal. These aspects are contained in sports; because of that, the sport has become a scientific discipline. Sport as a science is a structured and systematic set of knowledge about sports phenomena based on a scientific research system (Balagué et al., 2017). The study of sports science is then increasingly needed along with the times. Many aspects of life, including social, cultural, economic, political, and legal aspects, are closely correlated with physical elements. Therefore, sports science is one of the fields of science that is needed in life.

Sports have been around for a long time in Indonesia, even since traditional times. Previously, primitive Indonesian tribes used this physical activity closely related to arts, rituals, and self-defense. Entering the colonial period of the Dutch East Indies, Indonesia began to recognize the modern sports system brought by the Netherlands and by Germany after it. At that time, the sports that were gaining popularity were soccer and badminton. Then, after Indonesia's independence, the sports system in Indonesia entered a new phase and was free from foreign rules. For the first time in 1946, the Indonesian National Sports Committee (KONI) was established as a forum for the unity of sports for all regions in the country.

Along with the development of sports activities in Indonesia, sport is not only an activity to nourish the body but also as something to be competed with. This is marked by the emergence of sports competitions in Indonesia that compete in certain sports, such as soccer, badminton, volleyball, and basketball. Some have even started since the arrival of the Dutch East Indies, such as the Indonesian football league, which began in the 1930s. In addition to football, other sports competitions will emerge, such as the Indonesian Basketball League (IBL) for basketball, Proliga for volleyball, and the Indonesian Badminton Superliga for badminton.

In addition to single event sports competitions, Indonesia also actively participates in multi-event sports competitions, namely competitions with various sports that are competed. Indonesia routinely holds this kind of competition is the National Sports Week (PON), held every four years, and is participated by all provinces in Indonesia. PON was first born in 1948, with the city of Solo as the host in this event. In addition to national-level sports competitions, Indonesia has also 
begun to organize provincial-level competitions, such as the West Java Regional Sports Week (PORDA). West Java Porda is a four-year sporting event for athletes in West Java that has entered its 13th implementation in 2018. This implementation is technically carried out by the West Java Regional Sports Week (PB Porda). PB Porda becomes the planner and implementer in implementing the West Java Porda, which the West Java KONI will later evaluate.

The implementation of PORDA XIII in 2018 in Bogor Regency, West Java, was attended by 27 district/city contingents in the West Java region. The number of sports that were competed was 60 branches with a total of 879 match numbers. At the same time, the number of medals contested was 879 gold medals, 873 silver medals, and 1,171 bronze medals. The total number of athletes involved is estimated at 9,650 athletes and 3,800 officials. The PORDA XIII activity also involved approximately 11,000 organizing committees for both the sports and primary levels, namely the Grand Committee (PB). All matches were held in 60 venues (locations/places) spread over seven cities/regencies of West Java, namely: Bogor Regency, Bogor City, Depok City, Bandung City, Karawang Regency, Cimahi City, and Pangandaran Regency. With many participants, branches, numbers, and various complexities in implementing activities, governance is needed in organizing this multi-event. In this study, management is primarily aimed at the participant registration process and the problems that arise in it.

With all the existing problems, of course, management with good quality is needed to cover any issues related to the registration of West Java Regional Police XIII participants. The primary function of leadership is to organize a job so that the initial goals of the work can be achieved. Management is needed in all activities, including implementing sports competitions, both single and multi-event events. Management that includes POAC functions (planning, organizing, actuating, controlling) can help organize sports competitions neat and structured from all aspects, from planning to a final evaluation of activities (Arumsari, 2017). However, if the management is terrible, all existing problems cannot be handled properly, and it is even possible that new issues will be born. Therefore, the POAC function of this management must be deployed to the maximum to achieve maximum results. 


\section{METHODS}

The method used in this research is the descriptive method (Ramadan \& Juniarti, 2020). Explains that the descriptive method is a method that seeks to analyze and describe research facts and data (Sugiyono, 2010). Descriptive research is conducted to find data and facts in general as usual in the study and tell them based on a scientific approach. This research uses Henry Fayol's management function model, which consists of planning, organizing, actuating, and controlling (POAC) (Aditama, 2020). The POAC model was chosen because this model can analyze and describe the registration management of the 2018 West Java Porda XIII participants in total, from planning to supervision. The use of the POAC model identifies the dimensions to be studied, namely planning, organizing, actuating, and controlling The four dimensions are also variables in this study. The population in this study represents the overall potential sources of data and information, namely the General Chairperson of PB Porda, members of PB Porda, and the participant registration committee consisting of admin staff and IT staff. In addition, the participants also serve as user informants (registrants).

The sample is part of the population that is considered to represent the population. The sampling technique was done by convenience sampling. Convenience sampling is a non-probability sample design used to easily and quickly obtain information about the desired phenomena and variables. This sampling technique collects information from members of the population who can comfortably provide that information. The research instrument is a written guide on questionnaires or interviews, or observations prepared to obtain information from respondents; the data collection instrument in this study was carried out using various techniques.

\section{RESULTS AND DISCUSSION}

The West Java Regional Sports Week (Porda) is a multi-event sports competition regularly held every four years and involves various sports at the provincial level (Fitriasmara, 2017). Porda Jabar XIII was born in 2018 with Bogor Regency as the host and competed in 60 sports with several 879 matches. This 
made Porda Jabar XIII the Porda with the highest number of sports and match numbers. The total number of athletes involved is estimated at 9,650 athletes and 3,800 officials.

However, the implementation of the West Java Porda, which has entered its 13th event, does not make it free from problems, especially in the registration of participants. To analyze the existing problems, a study of the four functions of management was conducted.

Issues related to registration include setting match numbers. In determining the number of matches, the ideal time limit is four months before the competition. However, in Porda Jabar XIII, several match numbers were delivered suddenly, with a period of only two months before the match. The delay in determining the match number will undoubtedly affect the athletes' readiness to participate in the game. With a short and sudden time, the process of preparing athletes and their supporting equipment becomes even more narrow. As a result, the athletes who will be sent to participate in the competition feel pressured, and their quality is not optimal. However, related to this research, the delay in submitting match numbers will impact the registration system, especially if using the qualifying round (BK) system.

In the 2018 West Java PORDA XIII series of activities, the committee made various preparations from the beginning, both those that were directly related to the registration process, such as conducting qualifying activities $(\mathrm{BK})$ as the initial part of participant registration, or those that were not directly related to registration such as the preparation of a technical handbook (THB), which is a guide for the entire series of West Java PORDA XIII 2018. However, in the registration process, no BK data were found. Likewise, in the preparation of the THB, there were irregularities that the contents of the THB book contained many changes so that it would affect the process of the PORDA competition taking place.

The above problems should not occur if planning is done correctly. Planning as a plan determines how the registration process will be carried out, who will be the executor in each stage of implementation, where it will be held, what kind of system is being implemented, how is the readiness of personnel in carrying out each role in the registration, and so on. These elements must be planned from the outset to achieve the objectives of registration management. 
Some stages become the basis for the fulfillment in the planning function, such as setting goals, formulating current conditions, collecting data and facts, formulating possibilities or opportunities, and determining alternative steps. Choosing these stages is an effort to achieve goals effectively and efficiently.

The implementation of the planning function in the management of the 2018 West Java PORDA XIII participant registration, among others, is in the form of field readiness in planning for the implementation of participant registration. The Competition Field is the party that carries out the registration process for match participants.

In carrying out the planning function, the first step taken by the Match Field is to determine the goal. The purpose of participant registration management, which is carried out online, is to create an effective and efficient registration system to reduce time and other accommodations in the registration process. With online registration, the mechanism will be more straightforward because registrants from various contingents throughout West Java do not need to come directly to the registration committee (Field of Competition) in Bogor. The database is presented online and faster so that it will facilitate the steps in the data processing. With easy and fast data processing, the next steps in carrying out the match become quicker and more precise.

The realization of the following planning function taken by the Competition Division is to find out about the Qualification Round (BK) results, THB validation from the qualifying round, and the development of the PORDA participant list. From the search results, it turns out that three crucial things in the readiness of the Competition Field to start the task as a whole are very worrying because there is no data on the results of the BK, technical book (THB), which found many irregularities which indicate the weakness of the function of the manual. The next plan is the Field of Competition, which actively participates in building an information system to implement PORDA XIII West Java 2018. The development of this information system is an effort to minimize several stages that would take a long time if done conventionally. With the information system, there are time cuts and manual steps.

However, the implementation of the management function certainly does not stop there. Everything formulated since the beginning is then used as a basis for consideration in the division of tasks for organizing this competition. The 
management function in question is the organizing function. This is so that each job that must be done has a clear line of coordination and responsibility. With the organizing function, the resources owned will be distributed optimally. In organizing, it is necessary to analyze the capabilities of each HR so that their placement is by the powers of each implementing personnel. In this way, the tasks will be distributed and resolved optimally.

In carrying out a series of registration processes, the Competition Field as the executor consists of implementing personnel elements. Based on the organizing function, the personnel of the Competition Division is divided into division heads (1 person), financial manager (1 person), secretary concurrently member (1 person), members (20 people), experts (2 people), and IT admin ( 9 people).

Then comes the actuating function or execution. This function determines whether everything that has been formulated can run well. Overall, the implementation of the West Java Province XIII Porda is indeed considered quite successful. However, there are still some things that need further improvement. After going through the implementation process, it can be seen that the implementation of the West Java Regional Police XIII is still not fully following the original objectives of the Porda itself. As stated in PP No. 17 of 2007 Article 15, regional sports weeks are held periodically and continuously to improve sports performance, attract potential athletes, empower community participation in various sectors, and strengthen national unity and integrity. If viewed from the reality that occurred in the field, it can be stated that the implementation of the West Java Regional Police XIII is still not following the objectives. All the problems in the area that stick out to the surface, such as the delay in coaching athletes and the delay in determining the number of matches, will undoubtedly harm achieving the initial goal, which is none other than improving sports performance and attracting athletes. Coaching young athletes who are considered lacking in West Java Province XIII will undoubtedly make the selection of athletes' seeds not fully achieved. In addition, the sudden determination of several match numbers can make athletes lack time for preparation so that their performance on the field decreases.

Actuating in this research is the process of online registration activities by optimizing the information system. Information systems streamline communication between elements involved in implementing the 2018 West Java PORDA XIII series. 
The use of information systems by the Competition Division for the online registration/registration process for participants is in the form of registration forms $A$, $B, C 1, C 2$, and D. Form A relates to the number of participants, Form B relates to matching numbers, Form C1 relates to athlete's data, Form C2 relates to official data, and Form $D$ refers to data in charge of the contingent.

The description of each form, namely Form A, is a sports registration form that every participant will follow in the Regency/City area. This form will be presented the number of athletes and officials in each of the included sports. Form B is a sports registration form containing the contested numbers and names of athletes with complete biodata. Form B has certainty that will take part in PORDA Jabar XIII 2018 accompanied by a photo of a family card, photo of ID card, two documents between elementary/junior high school diploma (equivalent) or birth certificate/passport, color $4 \times 6$ photo, and a statement letter of willingness to strengthen West Java at PON XX 2020, as well as for athletes who are mutated from/between districts/cities in the West Java region, and from/between provinces must be accompanied by complete mutation requirements documents. Next, Form $\mathrm{C}$ related to athletes and officials is the registration format for names, accompanied by complete biodata and positions for officials and contingents of each district/city participant. Form $\mathrm{C}$ is attached with a Fiphoto of the ID card and a photo of a certificate (for trainers only). Finally, Form D is the format for the recapitulation of the number of athletes and officials, the arrival date of the contingent, and information on the address of the main contingent post from each district/city.

The Competition Field makes an effort to accelerate and effectively register participants, both athletes, and officials, which is carried out collectively by the contingent. Registration is done using a web-based online registration form with a login tool on the page: http://registrasi.pordajabar2018.id. The online form is a part/subsystem of SIMPORDA XIII as a whole. Each contingent has its unique user and code as a password to enter/login into the system. The following is the PORDA XIII online registration web display.

All deficiencies in the actuating function in West Java Province XIII are also related to the controlling role. There will always be an intense need for supervision in the implementation process from start to finish in whatever aspect it is. The party authorized to carry out this supervisory function is the Indonesian National Sports 
Committee $(\mathrm{KONI})$. This supervision is carried out to know whether planning and organizing have been appropriately implemented. If deficiencies are found in several aspects, they can be used as evaluations for implementing the following West Java Porda. In addition, this supervision is also carried out to determine whether there are urgent problems that must be resolved at that time.

For example, when an athlete's mutation occurs, KONI immediately intervenes by forming a Mutation Working Group to take care of the athlete's mutation verification process to resolve the modification.

\section{CONCLUSION}

The management function, which consists of planning (planning), organizing (organizing), actuating (implementing), and controlling (supervision), will always be needed in any organization or activity, be it small or large scale.

In organizing West Java Province XIII, the implementation of this management function will determine whether the performance can be said to be successful or not. The executive committee and other authorized parties have passed the four management functions, from planning to supervision. All matters relating to the West Java Regional Police XIII implementation have been designed and adapted to the original purpose of the Porda itself. Planning is strengthened by the division of tasks in organizing, which is closely related to implementation and supervision. Everything that has been formulated in planning and organizing can be judged to be successful or not visible when carrying out the implementation and monitoring functions.

Every problem found in the West Java Regional Police XIII will be used as evaluation materials for further improvement to implement a better Porda. This is, of course, the duty of all parties so that the objectives of Porda, as stated in PP No. 17 of 2007 Article 15, can be appropriately achieved.

\section{REFERENCES}

Aditama, R. A. (2020). Pengantar Manajemen Teori dan Aplikasi. AE Publishing.

Arumsari, N. R. (2017). Penerapan Planning, Organizing, Actuating, dan Controlling di UPTD Dikpora Kecamatan Jepara. Jurnal Ekonomi Bisnis Kontemporer, 3(2).

Balagué, N., Torrents, C., Hristovski, R., \& Kelso, J. A. S. (2017). Sport science integration: An evolutionary synthesis. European Journal of Sport Science, 17(1). 
https://doi.org/10.1080/17461391.2016.1198422

Bangun, S. Y. (2019). Peran Pelatih Olahraga Ekstrakurikuler dalam Mengembangkan Bakat dan Minat Olahraga pada Peserta Didik. JURNAL PRESTASI, 2(4). https://doi.org/10.24114/jp.v2i4.11913

Fitriasmara, D. (2017). Analisis Keunggulan Tim Putra Bola Basket Sidoarjo pada Porprov Jawa Timur 2015. Jurnal Prestasi Olahraga, 2.

Prasetyo, Y. (2015). Kesadaran Masyarakat Berolahraga untuk Peningkatan Kesehatan dan Pembangunan Nasional. MEDIKORA. https://doi.org/10.21831/medikora.v11i2.2819

Ramadan, G., \& Juniarti, Y. (2020) Metode penelitian: pendekatan kuantitatif, kualitatif dan R\&D. CV Sadari Press

Rohendi, A., \& Rustiawan, H. (2020). Kebutuhan Sport Science pada Bidang Olahraga Prestasi. JOURNAL RESPECS, 2(1). https://doi.org/10.31949/jr.v2i1.2013

Rubiyatno, R. (2014). Peranan Aktivitas Olahraga Bagi Tumbuh Kembang Anak. Jurnal Pendidikan Olahraga.

Sugiyono. (2010). Metode penelitian kuantitatif kualitatif dan $R \& D$. Alfabeta. 